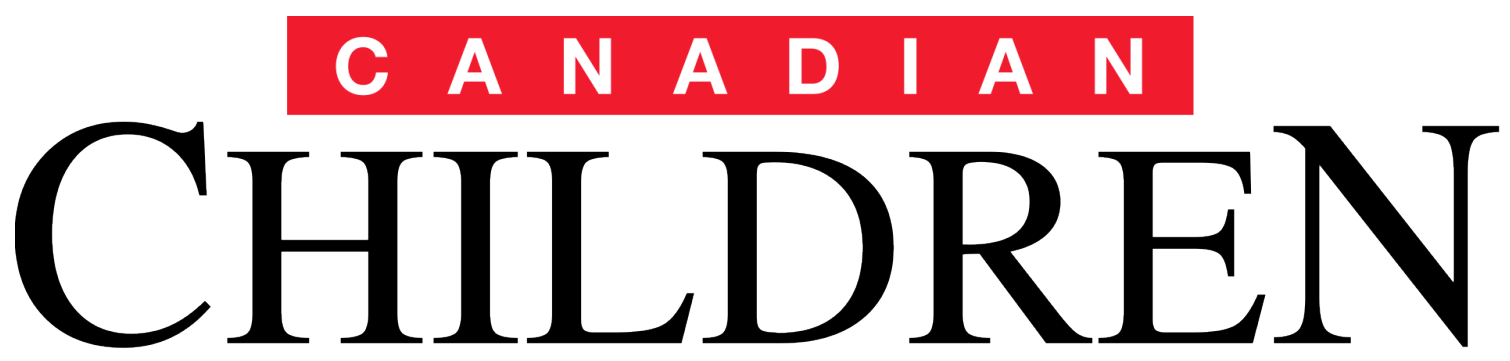

JOURNAL OF THE CANADIAN ASSOCIATION FOR YOUNG CHILDREN

Winter 2015/Hiver 2015

Vol. 40 No. 1

\title{
Authoring Professional Identities: Immigrant and Refugee Women's Experiences in an Early Childhood Teacher Education Program
}

By Christine Massing

\section{A N A D I A N}

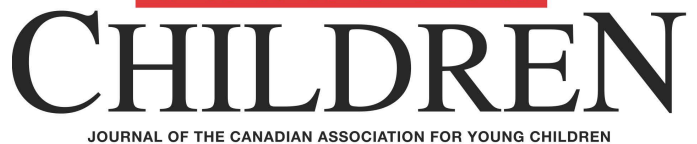

JOURNAL OF THE CANADIAN ASSOCIATION FOR YOUNG CHILDREN

Winter 2015/Hiver 2015

Vol. 40 No. 1

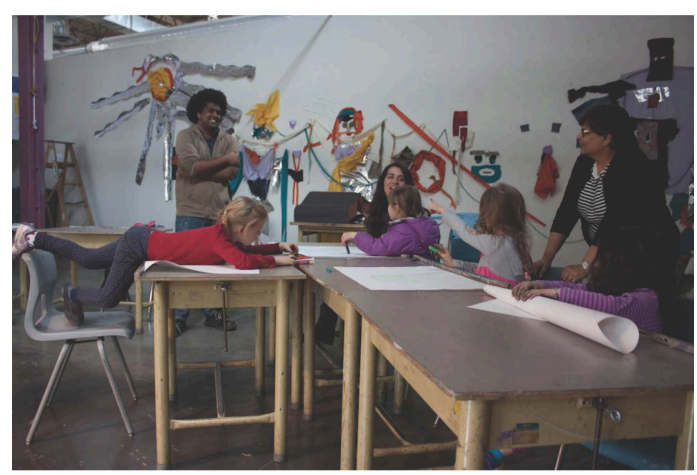

Editors:

Dr. Laurie Kocher, Douglas College, Coquitlam, British Columbia Dr. Veronica Pacini-Ketchabaw, University of Victoria, Victoria, British Columbia

Guest Editors, Special Issue: Professionalism in ECEC Dr. Rachel Langford, Dr. Jane Hewes, Sonya Hooper, and Monica Lysack

Publications Chairperson:

Dr. Iris Berger,

University of British Columbia,

Vancouver, British Columbia

Cover Photo:

Dr. Sylvia Kind

(C) 1996: The Canadian Association for Young Children ISSN: 0833-7519

Author Guidelines: visit www.cayc.ca

Published with support from the Social Sciences and Humanities Research Council of Canada

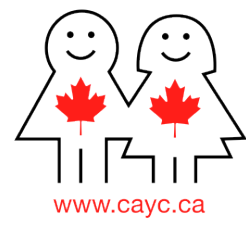




\title{
Canadian Children
}

\section{JOURNAL OF THE CANADIAN ASSOCIATION FOR YOUNG CHILDREN}

Volume 40 Number 12015 [page 73 to 99]

www.cayc.ca

\section{Professional Identities: Immigrant and Refugee Women's Experiences in an Early Childhood Teacher Education Program}

\section{by Christine Massing}

\begin{abstract}
Author's Bio
Christine Massing is a doctoral candidate in the Department of Elementary Education at the University of Alberta, specializing in early childhood education. She also instructs part time in the Early Learning and Child Care Program at Grant MacEwan University. Prior to undertaking her studies, Christine taught in Guatemala, Japan, Mexico, Colombia, Egypt, and Canada. Her research interests include immigrant and refugee studies, early childhood teacher education, professional identity construction, adult-child interactions, and familial involvement in child care programs. Email: christine.massing@ualberta.ca
\end{abstract}

\begin{abstract}
This one-year ethnographic study explored how immigrant and refugee women enrolled in an early childhood teacher education program constructed understandings of the authoritative discourse in their program in relation to their personal and cultural knowledges and beliefs. This article focuses on the participants' processes of learning to speak and act as professionals as made visible in their play interactions with children in their field placement sites. Although these participants were expected to appropriate normative practices, they in fact dialogically authored their own hybridized professional identities informed by their own understandings and the authoritative discourse.
\end{abstract}

Keywords: authoritative discourse, early childhood education, immigrants and refugees, play, professional identity, teacher education 


\section{Acknowledgements}

I am grateful to my research participants who so generously welcomed me into their classes and field placement sites and shared their stories and experiences with me. I would also like to thank my doctoral supervisor, Dr. Anna Kirova, and the two anonymous reviewers for their helpful comments on this paper. My doctoral research is supported by the Social Sciences and Humanities Research Council of Canada and the Killam Trusts.

Immigrant and refugee women may gravitate to the field of early childhood education (ECE) for various reasons: to benefit from the availability of positions both nationally and provincially (Beach, Friendly, Ferns, Prabhu, \& Forer, 2008), to enter a field that is widely viewed as very accessible to newcomers (Service Canada, 2011), or to draw on the experience they gained as teachers, mothers, aunts, siblings, and grandmothers in their home countries (Massing, 2014). It is unknown precisely how many immigrant and refugee women are employed in child care in Alberta, where this study took place, though anecdotal observations suggest they form well over half of the urban workforce. Statistics Canada (2010) foretells that the ethnocultural diversity of Canada's population will increase dramatically by 2031, when one in three people is projected to be a visible minority, one in four is expected to be foreign born, and more than one-third of these individuals are anticipated to be children. In view of these projections, it is imperative to recruit and retain educators who represent these groups (Souto-Manning \& Dice, 2007) because they possess the life experiences, cultural bridging and mediation skills, and cultural knowledges needed for working with children and families from similar backgrounds (Adair, Tobin, \& Arzubiaga; 2011; Bernheimer, 2003; Guyton, Saxton, \& Wesche, 1996; Wilgus, 2013). However, immigrant and refugee women who seek to increase their qualifications by enrolling in an early childhood teacher education (ECTE) diploma or certificate program experience unique challenges in their studies, particularly in field placements (Ortlipp \& Nuttall, 2011). ${ }^{\mathrm{i}}$

Students in ECTE programs are widely believed to come with preexisting beliefs about teaching, learning, and the adult role which may be derived from their personal histories and theories (Lopes \& Pereira, 2012; Stenberg, Karlsson, Pitkaniemi, \& Maaranen, 2014), their experiences as students in the school system (Brown \& Feger, 2010; Furlong, 2013) their prior experiences working in the field (Horsley \& Bauer, 2010), or their personal experiences as mothers or familial caregivers (Osgood, 2012; Vincent \& Braun, 2011). Cultural background is deemed to play an especially powerful role in shaping one's beliefs and practices (Gupta, 2011; Quiocho \& Rios, 2000). Britzman (2003) has theorized that students are inhabited by "cultural myths" or stereotypes about what it means to be an educator informed by these personal biographies. Students convey these myths about their professional role into their 
coursework or field experiences, where they either inhibit or create possibilities for professional identity construction. Immigrant and refugee women may experience an especially profound dissonance between the Euro-North-American content and expectations of the program and their own cultural beliefs, knowledges, experiences, and values (Gupta, 2006). Previous research has suggested that these women feel compelled to adopt program expectations at the expense of their own beliefs (Moles, 2014; Nuttall \& Ortlipp, 2012).

In this article, I describe how immigrant and refugee women enrolled in one ECTE certificate program in urban Alberta experienced this disjuncture while negotiating their professional identities. After describing the context, theory, literature, and methodology informing this study, I briefly outline the participants' own experiences with learning, teaching, and play as a counterpoint to the "learning through play" theory studied in their coursework. Then, I utilize a series of excerpts from my field observations in their field placement sites to make visible some of these negotiations. I argue that although these immigrant and refugee students were expected to appropriate normative professional practices, they in fact dialogically authored their own hybridized professional identities informed by both their personal biographies and the authoritative discourse of early childhood education.

\section{The Context of the Authoritative Discourse}

Discourses have been defined in a general sense as "ways of talking, listening, reading, writing, acting, interacting, believing, valuing and using tools and objects in particular settings and at specific times so as to display or recognize a particular social identity" (Gee, Hull, \& Lankshear, 1996, p. 10). Bakhtin (1981) more explicitly described an authoritative discourse as being infused with historically derived power and authority, binding us and demanding "unconditional allegiance" (p. 343). In the ECE field, Western child development theory has long been upheld as the authoritative knowledge base. It is embodied within texts, policies, regulations, standards, and programs and has evolved into a set of defined, prescriptive ways of being with, teaching, and caring for young children. This quantifiable, scientific, technical knowledge exerts dominance over the practical knowledge that shapes our "daily actions in the world" (McLaren, 1989, p. 170). In the context of child care, practical knowledge emerges out of one's personal experiences, beliefs, values, and relationships with children. Reconceptualist scholars have long problematized this authoritative discourse for proposing a universal and essentialized childhood whereby all children progress through the same developmental stages irrespective of the familial, social, and cultural contexts in which they live their lives (e.g., Cannella, 1997; Lubeck, 1996; Ludlow \& Berkley, 1994; Dahlberg, Moss, \& Pence, 1999, 2007). In spite of this critique, culture is still largely appended to the existing discourse (Fleer, 2006).

\section{Canadian Children}


Educators' professional knowledge, then, is predominantly defined as theoretical knowledge of Western child development and "developmentally appropriate practices" (National Association for the Education of Young Children, 2009). Accordingly, the dominant construction of the professional, Moss (2006) argues, is that of a technician who assumes an educative role by transmitting and applying "a defined set of technologies through regulated processes to produce pre-specified and measurable outcomes" (p. 35). When the educator's role is conceived of in such terms, professional autonomy is subsumed beneath the perceived power of the authoritative discourse (Langford, 2010; Osgood, 2006, 2012). Urban (2008) explains that when professionalism is defined by these external frameworks, "it is almost impossible (for educators) to make judgements themselves in a way that is relevant for their actual working context (i.e., the particular children, families, and communities they are working with)" (p. 142).

ECTE programs similarly promote the view of the professional educator as a technician (Lobman \& Ryan, 2007; Woodrow, 2008) bound to the authoritative discourse as operationalized in provincial standards, regulations, and curriculum frameworks. These scientific approaches "necessarily eliminate culturally based understandings about teaching and learning that teacher candidates bring to their teacher preparation" (Montecinos, 2004, cited in Wilgus, 2013, p. 7). Even if ECTE programs are desirous of shifting toward a sociocultural framework, the pervasiveness of the authoritative discourse in field placement sites poses challenges to doing so (Garavuso, 2013). This universal, mythologized view of the educator as a technician therefore perpetuates notions of identity as predetermined and immovable, something that is assumed rather than constructed (Britzman, 2003).

\section{The Authoritative Discourse in Alberta}

In the Alberta context, regulated child care centres or family day homes are overseen by the Ministry of Human Services and existing frameworks privilege child development knowledge. For example, the Child Care Licensing Act (Government of Alberta, 2013a) defines programs and types of staff certification and mandates program requirements with a particular emphasis on the health and safety of children and children's developmental needs and capabilities. The Government of Alberta (2013b) delineates three levels of staff certification (child development assistant, worker, or supervisor) incorporating some child development coursework. While there is no official

code of ethics, the Alberta Child Care Accreditation Program (ACCAP) standards expand on the legislation to promote and measure program "quality" (Alberta Association for Accreditation of Early Learning Services, 2011). According to Lirette (2012), though, the standards, outcomes, and indicators are rigidly defined, prescribing very specific interactional styles and practices within the dominant construction of professionalism. These "official" definitions of professional practice foreground the authoritative discourse and advance narrow definitions of what the professional educator should do 
(Fenech, Sumison, \& Shepherd, 2010), thus marginalizing educators' own practical knowledges (Colley, 2006; Moyles, 2001).

\section{Conceptual Framework: Communities of Practice}

This study is framed by sociocultural-historical theory (Vygotsky, 1978) and informed by Lave and Wenger's (1991) concept of communities of practice. In any community of practice, as ECE is commonly conceived to be (Egan, 2009; Fleer, 2003) ${ }^{\mathrm{ii}}$, members are mutually engaged in joint enterprise as they develop a shared repertoire of practice, including actions, language, and artifacts (Wenger, 1998). As new members (or "newcomers") actively participate with others and gain access to the community's historically developed sources for understanding, they move closer to becoming full, legitimate participants. ECTE instructors and field placement supervisors ("oldtimers") might apprentice students (newcomers) into the community by helping them develop the skills and knowledges required for future employment in ECE settings. These "sources for understanding" might include the licensing regulations, accreditation standards, policies, developmental theories, and day-to-day practices that constitute the authoritative discourse as understood by that particular community.

Identity, which Wenger (1998) has conceptualized as the counterpart to practice, is defined by several elements, including negotiated experience, community membership, a learning trajectory, a nexus of multimembership, and a relation between the local and the global. First of all, Wenger (1998) explains that "we define who we are by the ways we experience our selves through participation as well as by the ways we and others reify our selves" (p. 149). The experience of engaging in practice with others allows one to produce an identity within the community. In addition, becoming a full member by achieving a certain level of competence or expertise in the authoritative discourse contributes to identity formation (see also Karila, 2008; Thomas, 2012). Wenger (2000) maintains that newcomers are perceived as knowing or having learned if they have not only gained competence in the ways of acting, speaking, and being in the community, but also can apply their own personal experience to redefine these competencies. As Sachs (2003) has written, this personal dimension, including experiences, beliefs, and values, influences how each individual "translates" and enacts the authoritative discourse. Hence identity develops in relation as other members of the community contribute to the formation of the self and the individual defines herself in relation to others.

Identity is also conceived of as a nonlinear learning trajectory, thus identity construction is temporal, fluid, and continuously shifting (Wenger, 1998). It is an ongoing negotiation among the past, present, and future shaped by the oldtimers' and the newcomers' individual and collective sense making in specific sociocultural contexts. A trajectory leading to admission or acceptance in the community satisfies a desire for recognition (Packer \& Goicoechea, 2000) and fosters a sense of belonging in the 
individual (Moloney, 2010). Packer and Goicoechea (2000) explain that becoming a legitimate member in a community of practice may define who we are, but "also confronts us as something alien, so we are divided from ourselves and need to discover ourselves" (p. 234). In other words, the process of negotiating an identity is a struggle wherein the individual may become ontologically split between the person they once were ("back home," for example) and the person they are becoming in the community.

Next, identity in practice always represents an interplay between the local and the global (Wenger, 1998). For instance, Ortlipp, Arthur, and Woodrow (2011) argue that since local practice is informed by regulations, standards, and curriculum documents, changes in these frameworks impact professional identity construction, especially in new educators. Finally, individuals always belong to multiple communities, which may deviate in terms of ways of being and acting. For this reason, educators move fluidly among multiple, often competing, discourses in practice (Alsup, 2006; Miller Marsh, 2003). Field placements, Lamote and Engels (2010) clarify, may represent a new culture or community with norms and values that differ from those in the program. Immigrants and refugees also experience a disjuncture between discourses as they move from one context and belief system to another (Wenger, 1998). Bakhtin's (1981, 1986) conceptualizations of internally persuasive discourse and dialogism further elucidate how these students might negotiate these discontinuities.

\section{Dialogism and Internally Persuasive Discourse}

When newcomers participate in the practice of a community, as in the field placement site or workplace, it permits them to learn "how to talk (and be silent) in the manner of full participants" (Lave \& Wenger, 1991, p. 105). This aspect of the apprenticeship is particularly important given that professions have a social language (Bakhtin, 1986); that is, there are distinct types of jargon, words, and phrases that one must access and utilize to be construed as a professional. This shared social language is structured by the authoritative discourse, functioning as the "language of truth" bound to ideology and a specific worldview (Bakhtin, 1981, p. 367). Since one must have mastered English to learn the social language, immigrant and refugee students who are still in the receptive stage of English language acquisition may have difficulties apprehending the social language. Bakhtin further theorizes that because all languages are historically and collectively developed, they derive meaning and power from the heteroglossia, or the context in which they are spoken or written. Consequently whenever we speak, our utterances are deemed to be half our own and half someone else's, situated in both the past and the present: "One may speak of another's discourse only with the help of that alien discourse" (Bakhtin, 1981, p. 355). Our voice becomes our own only when we imbue words with our own intentions, accents, and meanings (Wertsch, 1998). These concepts apply not only to language as in words and texts, but also more broadly to actions, practices, knowledges, ideas, beliefs, and values.

\section{Canadian Children}


The authoritative discourse, as inscribed formally in texts and regulations and informally in ways of speaking, acting, being, and knowing within the community of practice, is not merely transmitted to a passive learner. Rather, it must be or become what Bakhtin (1981) called an internally persuasive discourse, "tightly interwoven with one's own word" (p. 345). Matusov and von Duyke (2010) emphasize that a discourse comes to be internally persuasive to the individual when the meaning of these words, knowledges, approaches, and ideas are negotiated, questioned, and tested by the student in dialogue with others, with the self, and with discourse. This process may present unique challenges to immigrant and refugee learners. If dialogue is the basis for composing internally persuasive discourses, then language can create disadvantage for these students. Furthermore, since discourse is embedded in the heteroglossia, students who are new to Canada do not have full access to the traditions and meanings of these words, approaches, and ideas (Landay, 2004). Phrases and words such as "learning through play" and "childcentred practice" present as abstract ideas that have been reified into a context-bound set of practices confronting immigrant and refugee students as "alien" (Fleer, 2003; Wenger, 1998). Finally, these students are far more likely to find dissonance between the "ideologically saturated" authoritative discourse (Bakhtin, 1981, p. 271) and their own personally and culturally formed beliefs, values, and worldviews, as outlined in the section that follows.

\section{Culturally and Linguistically Diverse ECTE Students and Educators}

To date, very few studies focus on the experiences of immigrant and refugee early childhood educators or ECTE students, especially in relation to professional identity development, but existing studies do provide some insights into their encounters with the authoritative discourse. In the context of ECTE programs, Moles (2014), who interviewed immigrant ECTE students in New Zealand, stated that the students had contested identities because their perspectives on the role of the teacher were not represented in the dominant discourse. For example, one student with a well-established identity as a leader and holder of knowledge in her cultural community shared that she struggled to make sense of the program content since "the things I knew are not here" (p. 173). When Langford (2007) interviewed instructors and analyzed textbooks and student assignments, she found that Canadian instructors utilized child development theory to quash diverse students' own cultural and linguistic knowledges. The diverse student, Langford claims, appears to be "viewed as less competent (and thus is more marginalized) because first she must learn discourses that are assumed to be commonsense, and second she must shed cultural and material practices (such as teacherdirection) incompatible with those of the good ECE" (Langford, 2006, p. 118). Not surprisingly, by the end of the program most of the students purged any of their cultural practices and beliefs that competed with the notion of the "good" early childhood educator, retaining only superficial signifiers of their cultural identities in practice. In Australia, Nuttall and Ortlipp (2012) interviewed culturally and linguistically diverse 
students after their field placements. Positioned by her supervisor within a discourse of "difference as deficit," one student commented that she needed to "become someone she would not be "in real life" in order to pass her placement (p. 57). She reconstructed her identity as an educator by erasing her difference and imitating her supervisor. These findings were consistent with those in the much more substantial body of literature on international or internationally trained preservice teachers in the field of teacher education, which emphasize that students need to change their beliefs and practices to successfully fit in the existing system (e.g., Agbenyega, 2012; Cho, 2010; Feuerverger, 1997; Myles, Cheng, \& Wang, 2006; Walsh, Brigham, \& Wang, 2011). Consequently, the perceived power of the authoritative discourse may lead these immigrant and refugee ECTE students to engage in "performative professionalism" (Taggert, 2011), suppressing their personal and cultural beliefs in favour of enacting the professional practices expected in the community of practice.

With respect to practicing educators, Adair, Tobin, and Arzubiaga (2011) found that "many immigrant teachers described their journey to becoming professional as one of having to give up old beliefs as well as to acquire new ones" because they were made to believe that their cultural knowledges were incompatible with the professional knowledge they had learned in the ECTE program and workplace (p. 11). Jipson (1991) concurred that diverse educators adopted practices which they personally found to be “culturally inappropriate." Huijbregts, Leseman, and Tavecchio's (2008) quantitative findings propose that immigrant and refugee educators trained in Holland adhered closely to the authoritative discourse in the workplace, but their responses suggest that they still retained culturally informed child-rearing beliefs and practices at home with their own children. Similarly, the Latina educators in Wilgus's (2006) study of disciplinary beliefs and strategies did not simply enact the authoritative discourse, but critically evaluated ideas they had learned in the ECTE program, actively deciding which to embrace and which to discard (p. 265). In these latter two cases, then, the educators seemed to pursue a trajectory leading to competence and acceptance within the professional community of practice while simultaneously maintaining some of the beliefs of their cultural communities.

\section{Methodology}

With the exception of Wilgus's study, previous studies have relied solely on selfreported data, but researchers have identified substantial gaps between educators' selfreported beliefs and actual teaching practices (e.g., Wen, Elicker, \& McMullen, 2011). The overall purpose of this study, then, was to gain insights into how immigrant and refugee women experience their studies and field placements in an ECTE program by using an ethnographic methodology over a sustained period of time. Ethnography has been used in studies of culturally diverse teachers in the school system "in the hopes of making visible and meaningful the complexity of what is usually not seen" (Quiocho \&

\section{Canadian Children}


Rios, 2000, p. 494). Three questions framed the research: (1) What understandings do immigrant women in one ECE program construct of the dominant discourse in ECE? (2) What impact do these understandings have on their perceptions of themselves in relation to children as they negotiate their professional identities as ECE teachers? (3) How does their learning in this program influence their interactions with children in their field experiences?

\section{Research site and participants}

The research site was a large urban community college in Alberta offering a variety of upgrading and ESL courses, as well as postsecondary certificate and diploma programs. The college enrolls a high proportion of immigrant and refugee learners, particularly women, who are often eligible for government funding for language and career training. Twenty immigrant and refugee women - five from China, one from India, four from the Middle East, and ten from Africa - enrolled in a ten-month ECE certificate program (referred to as an ECTE program in this article) participated in the study. In this article, I focus on six African/Middle Eastern students (see Table 1) whom I observed on field placement and who constituted a "culture sharing group" (I have noted instances where their experiences or viewpoints differed). Their experiences cannot be generalized to other students coming from the same countries. These women all came from comparatively affluent families, grew up in urban centres, are mothers, and are Muslim. Geena and Jasmine came to Canada as immigrants while the other women came as refugees.

Table 1. Study participants.

\begin{tabular}{|l|l|l|l|}
\hline Pseudonym & \multicolumn{1}{|c|}{ Age } & \multicolumn{1}{c|}{ Home Country } & \multicolumn{1}{c|}{ Prior Experience } \\
\hline Ameena & Late 20s & Ethiopia & $\begin{array}{l}\text { Mother of three preschool-aged } \\
\text { children }\end{array}$ \\
\hline Asmaa & Late 20s & $\begin{array}{l}\text { Somalia (spent part of } \\
\text { childhood in Yemen) }\end{array}$ & Mother of one school-aged child \\
\hline Bijou & Mid-20s & $\begin{array}{l}\text { Sudan (spent part of } \\
\text { childhood in Senegal and } \\
\text { Central African Republic) }\end{array}$ & $\begin{array}{l}\text { Mother of two school-aged children } \\
\text { Began teacher training back home } \\
\text { and worked in child care in Canada }\end{array}$ \\
\hline Fatima & Early 50s & Somalia & $\begin{array}{l}\text { Mother of four grown children and } \\
\text { one school-aged child }\end{array}$ \\
\hline Geena & Early 40s & Sudan & Mother of two school-aged children \\
\hline Jasmine & Late 30s & $\begin{array}{l}\text { Syria (spent childhood in } \\
\text { Kuwait) }\end{array}$ & Mother of four school-aged children \\
\hline
\end{tabular}




\section{Data collection and analysis}

I was a participant-observer situated within the students' day-to-day experiences in this program for two to three full days a week from September to June during their courses, breaks, special events, and field placements. Qualitative data were collected through observational field notes (at the college and in field placement sites), interviews, focus groups, informal conversations, spatial maps, and artifacts/documents (field placement evaluations, class notes, assignments, assessments, artistic creations, and class work). Participants were interviewed two to six times throughout the year for 30-45 minutes and took part in up to four 60 -minute focus groups. I obtained permission to observe seven of the participants for half a day each week during their term two field placements in four different accredited child care centres. I analyzed the data descriptively by doing an overview reading of the textual and oral data as they were being collected. Once I identified areas of dissonance and congruence with the students' own cultural practices during classes, interviews, and focus groups, I was particularly attentive to these notions as operationalized in the field placement sites. I used open coding to categorize and identify themes, and, upon completion of the data collection, I read these patterns theoretically based on the literature (Angrosino, 2007).

In the next section, I provide some context to the students' commonly held understandings with respect to the adult role during play and teaching/learning in their home countries in order to juxtapose their experiences with the authoritative discourse on "learning through play" that they learned in the ECTE program. Then, I present the findings in the form of a series of excerpts from my field notes detailing participants' interactions with children that revealed elements from their dialogues with the authoritative discourse as they attempted to make them internally persuasive.

\section{The Context of Play, Learning, and Teaching "Back Home"}

The participants brought with them to the ECTE program very specific notions about the separation of play and learning based on their own preschool experiences. From the time they could walk, all participants recalled playing outdoors with siblings and other children in the community. These times were often largely unsupervised by adults, though a parent would check on them occasionally and neighbours might admonish the children to go home if they were still out at night time. As Ameena recalled: "Mostly we played outside with other children, with the neighbours. It's not like here. They just send you outside.... We play outside, we enjoy and then we come back, like, night time. But here, 24/7 the kids stick with you" (interview, Feb 28, 2013). The adult role in play, then, was one of an occasional supervisor who steps in when problems arise.

The interactional patterns between adult and child affirmed this relationship as adults remained standing and more distant from the children. Geena confirmed: "I have to sit down on the ground or be at the same level? We don't have this" (interview, February 
28, 2013). Similarly, Ameena stated: "We never sit with the children face to face. We don't talk that much" (interview, February 28, 2013). Jasmine, then, was "shocked and surprised" when an educator knelt down and talked extensively with a child (interview, February 25, 2013). Interactions were also more nonverbal and less conversational than those back home. For example, Fatima stated that asking questions as parents might do in Canada was rare: "Most parents don't ask a lot, just like 'what are you doing?' when the child is doing something. The open-ended [questions]? No, they never do" (interview, June 25, 2013). Only infants, then, were held and "played with" or sung to. Although conversations between adults and children were uncommon, in their experience, everyone recalled that parents or grandparents sang to them or told them stories orally. These songs and stories were not shared with the goal of fostering literacy skills, though, but rather to transmit cultural values, guide behaviour, or convey encouragement or familial hopes for the child (Massing, 2014).

While the participants experienced a great degree of freedom in their childhood play, the adult role in the context of formal schooling was more prescribed and directive. Only Geena had had the experience of attending preschool (with a private religion tutor on the weekends), while the others attended preparatory madrassas, or religious schools, starting at the age of four or five and then advanced to the school system upon completion (usually one year). Early experiences in school were overwhelmingly associated with literacy and numeracy skills or "numbers and ABCs." Beginning in the madrassa, children were taught to read, primarily through memorization, as Fatima explained:

We learn how to read and write the Quran and then you take a Quran test.... You are not looking at your book. They ask you story number one, you have to say it. Number five, you have to say it. So you go to grade one, you know the Quran, you know Arabic. That's what we learn first. (interview, October 23, 2012)

According to Bijou, a school teacher might write a passage on the board, then "you copy it. You go home. You make sure you memorize" (interview, May 14, 2013). None of the participants remembered having educational toys or materials in their classrooms apart from paper and writing implements and the occasional book. As Ameena declared, "Just in our minds and write it down, no materials" (interview, February 28, 2013).

In the madrassa, children also learned values such as respect and honesty and "how to behave," as children were expected to listen and obey. Pedagogically, teachers asked closed-ended questions to test children's skills in memorizing the content and, as students, they were expected to respond. Bijou affirmed that this style helped her to retain information: "Everything is in your head.... Our teacher gave us the questions, we made 
the answers, but he made your brain go beyond what you know, and why. This way you get smart" (focus group, December 4, 2012). Not surprisingly, then, there was a strict separation in the women's minds between play and learning; play is free, unsupervised time whereas learning is formal, structured, and highly controlled. Geena explained this distinction: "If we are learning $\mathrm{ABCs}$, we have to sit in a desk, not like here playing and learning $\mathrm{ABCs}$, like, we had to sit and I had a pencil and tried to write $\mathrm{ABC}$ or $123 \ldots$ No playing. You can't play while you are learning. If you want to play, you play outside" (interview, February 28, 2013).

\section{The Authoritative Discourse: The Adult Role in Teaching and Learning}

At the end of the first term of the program, the students took a course entitled "Learning Through Play" in which they learned about the characteristics of play, play theory, play and development, the play environment, planning for play experiences (both experiences and centres), and the adult role in play. They studied the distinctions between child-directed and adult-directed activity as well as open-ended and closed-ended activities. Resonant with the participants' own experiences, the instructors, learning materials, and texts also privileged literacy and numeracy learning; however, these were often disguised as games, activities, or centres. As Sherwood and Reifel (2010) also found, singing songs was classified as "play." A secondary goal of the course was to expose the students to a wide variety of unfamiliar toys, art supplies, books, natural materials, and musical instruments which they might encounter in the field. Throughout the year, they utilized these materials as they explored or planned an array of centres: dramatic play, art, sensory, literacy, or numeracy. By second term, most students were able to plan and set up "learning centres" to encourage open-ended, child-directed play based on the children's interests. Many of the students came to associate the provision of such centres or experiences as consistent with their role as a professional.

In terms of the adult role, the students were taught to be actively involved in play by playing with the children, being on the floor with children, adding materials to extend play, modelling appropriate play and language, answering children's questions, and asking open-ended questions (e.g., "Can you tell me about ... ?”; course learning guide). Given that their own childhood play experiences had been child-directed and their school experiences had been adult-directed, the addition of an adult supervisor/educator during play was particularly difficult for the students to envision. So, although they understood the concept of child-directed play as defined in this course - the child chooses the activity, is in charge of the play, has a goal for play, and there is no expected end product - having the adult follow the child's lead or play with the child was not within the realm of their experiences. Rather, they alternately imagined the adult as a teacher or a supervisor who would stand, observe, and ensure their safety. 
In their coursework, then, the students had the opportunity to engage in dialogue with this authoritative discourse and form opinions about its content and use. As Bakhtin (1981) has described, the student may draw a word or idea into her own conceptual system, establish "a series of complex interrelationships, consonances and dissonances with the word," and then formulate a response (p. 282). Different conceptual horizons and social languages come into dialogue as interlocutors (both people and texts) interact. These participants accessed their own cultural myths related to what an educator should do and juxtaposed them with the content they were learning in the program, moving back and forth between conceptual systems to make meaning. While on field placement, their actions and interactions with the children made visible, in a sense, this process of negotiating and dialoguing with the authoritative discourse so that it would become internally persuasive. In the next section, representative vignettes from their field placements, examples that the participants themselves define as "learning through play," have been chosen to exemplify some variations of these dialogues.

\section{Dialogues with the Authoritative Discourse}

Few participants seemed entirely convinced that play was an efficacious means of learning all-important literacy and numeracy skills given their personal histories whereby learning and play were separated. Jasmine and Geena, in particular, concurred that their parents taught them that "academics" - numbers and ABCs — are most important, then playing. Geena confirmed:

If I send my kids to the kindergarten (back home), you know, the basic things like reading, story time is very important. I don't know why they think playing is important (in Canada). I understand that learning through play is important here. Back home, not exactly. They are playing outside ... adults leave them to play what they want. (focus group discussion, December 13, 2012)

In view of this disconnect, assuming the concomitant adult role in "learning through play" proved challenging for both of the women once on field placement, as can been seen in the following excerpts from my field notes.

At 10:44 in the morning, Jasmine is seated on a child-sized chair in the reading area in the middle of the preschool room. Two boys are building with DUPLO ${ }^{\mathrm{TM}}$ blocks in front of her. She sits on the floor between the boys and asks the first boy, James, "what's this?" He tells her it's a bridge. "What colour is it?" she asks him. He explains that he has a car that will go on the bridge he has built out of the DUPLO. She turns to the other boy, Blake, and asks "who's this?" He states that it's his sister. She turns back to James: "I'm going to build something with you." Jasmine picks up blocks one at a time_- "What colour is this? And this? And this? Very

\section{Canadian Children}


good"- before placing them back down on the floor. James tells her he has more blocks at home. "Oh, at home" she repeats. "You can use this one too if you want to," she tells him as she hands him a block. She turns to Blake, asks him if he has a car. Not waiting for an answer, she turns back to James and says "what's this? It's a window. It's huge. Oh, look at this" she says as she hands him a block. "Do you know what this letter is? Do you know?" James replies, "No." Jasmine asks him, "Do you want to know?" and James again replies "no." Jasmine says "okay" and sits back up on her chair. (field notes, February 13, 2013)

In the following short excerpt from a play episode, Geena was drawn into pretend play with two children (nearly three years old) and seated herself on a child-sized chair in the dramatic play area.

Emily is cooking on the stove and Geena asks her, "What's this? What's this? ... Are you going to put it on a plate like that? Yeah good. Where's the fork? Where's the fork?" Emily hands her a spoon. Geena says, "That's not the fork." Guessing that Emily may have a different plan, Geena says, "Okay, you are going to mix it? Are you going to put salt? No salt? Breakfast is now ready? Put this here. Where's the milk? Where is the milk? We need to put milk in the cereal." (field notes, February 12, 2013)

Both Jasmine and Geena incorporated elements of the authoritative discourse into their interactions: sitting at the children's level, interacting with the children, and asking them questions. However, both women seemed uncomfortable joining the children's play and instead performed as a "teacher," a role consistent with their own experiences back home. They bombarded the children with closed-ended "test" questions such as "what's this?" and "who's this?" Jasmine quizzed James on his knowledge of colours and attempted to introduce a lesson on letters. Geena sought to teach by directing Emily's play and correcting her mistakes, which resonated with her own school experiences. Consistent with a North American view, the authoritative discourse mandated asking questions to stimulate conversation, demonstrate interest, and extend play, but Jasmine and Geena invoked a didactic understanding of instructing through questioning and testing knowledge. These questions operated as hybrid constructions, spoken by a single speaker but belonging simultaneously to two intersecting belief systems (Bakhtin, 1981). While each woman was in dialogue here with the authoritative discourse, their interactions with the children implied monologue or transmission of knowledge rather than dialogue or co-construction of understanding.

While many participants did make attempts to play with the children, more often they fell easily into this teaching role when invited to play. Their instructors had

\section{Canadian Children}


introduced them to many children's songs and books, and had them manufacture story props or games to be used with various texts. The authoritative discourse regulated how they should "do" story time: sitting on the floor (or a short chair) at the children's level, holding up the book so the children could see, asking open-ended questions, and involving children with the props (class handout). Ameena was surprised by this aspect of the program because, back home, parents, not teachers, sang to children: "I know in back home we sing for the children, but in school? I never see like that" (October 3, 2012). In the professional context, Ameena strongly believed that her role was to teach the children and prepare them for school: "If I just watch over them, feed them, if I don't teach them anything, when they go to school they get a surprise. No. I'm going to teach them numbers, ABCs" (October 3, 2012). Therefore, when Amy approached the dollhouse next to where Ameena was sitting and invited her to play, Ameena instead diverted her toward the "game" she had brought: a Five Little Ducks book with felt board props.

"I have a new game for you," she says to Amy enticingly. A large cluster of children soon join her as she walks to the reading area with Amy, the book, and the props. Eight children gather around her, sitting on the floor as Ameena sits on a chair. She holds the book in her lap and reads the first verse out loud. Evan asks, "Where is daddy?" and Ameena responds: "Daddy come after, yeah, he called the next one. Quack, quack, quack, quack (she pronounces the sound in her language and it sounds like "quock"). Three little duckie, one go swimming over the hill and far away. Mother duck call quack, quack, quack. How does she quack? Who can tell me? Yay" she says as she claps her hands. Ameena reads the book two more times, each time in a slightly different way as she seems to rely less on the words and more on her memory to interpret the words in her own way. During these readings, three of the children use the felt board, manipulating the ducks as she speaks. (field notes, February 11, 2013)

While Ameena had memorized the song in class, she chose instead to sing from the book, holding it on her lap so she could rely on the text to guide her interactions with the children. The song represented the words of another, derived from an unfamiliar sociocultural context; however, through her dialogue with the text and with the children, Ameena made the authoritative discourse (the text and her learning in the program) internally persuasive. The content of the song reassured her that she was teaching the children numeracy skills. As she altered the words of the song and made the duck's cry in her home language, she populated the words of the song with her own accents and meanings in a playful manner, constructing her own way of speaking within this community of practice rather than mechanistically reproducing the words as written in this authoritative text. The act of reading and singing thus became what Bakhtin (1981) referred to as double-voiced discourse: a dialogue of "two voices, two worldviews, and two languages" (p. 325). The words belonged both to the text (author) and to Ameena,

\section{Canadian Children}


and in the dialogue between them, she produced her own professional voice (see also Knoeller, 2004).

In the final vignette, Asmaa was engaged in block play with two 3-year-old boys.

Asmaa is sitting down on the floor. Kevin, sitting to her left, asks for assistance in pushing together DUPLO blocks. She holds the structure for him as he adds blocks. It seems to resemble an airplane. They work silently, attaching blocks to the building plate to fashion what is perhaps a landing strip. He picks up the airplane with his right hand and adjusts it. Asmaa turns her attention to a basket of Tinker Toys ${ }^{\mathrm{TM}}$ and begins spearing sticks into the connectors. She seems to be building a vehicle. Kevin sits to her left and appears to be observing what she is doing as he tries out his airplane, but she is concentrating fully on her own work. Kevin also begins to extract parts from the basket, trying to put a stick in the hole. Ethan, playing nearby, indicates her car with his finger and Asmaa gives it to him. "This is a nice car," he comments. Asmaa does not speak. She chooses a few more blocks to build with, but then the educator proclaims that it is time to clean up. (field notes, February 12, 2013)

Asmaa was cognizant of the expectation that she sit on the floor and "play with" the children, but she interpreted this role in a different manner. Contrary to dominant practice, which would emphasize role modelling language and asking questions (Heath, 1983), this episode was a rich, nonverbal, embodied interchange as Asmaa spoke only once during the entire ten-minute play episode. However, she was still acutely aware of the children, responding to Ethan's expression of interest in the car, and her rich nonverbal messages invited the children to be with her. She explained to me that in Somalia people believe that "if you are a good person, they come. The kids all come beside you. But if you are not a good person, they don't like you. Children know" (interview, February 20, 2013). Therefore, Asmaa saw verbalizing and questioning as superfluous. She felt that since children were drawn to be with her, they perceived her to be a "good person," a challenge to the adult role presented in the authoritative discourse. In this manner, she was constructing her professional identity dialogically but nonverbally with these children as she played alongside them.

Within the community of practice, then, these immigrant and refugee ECTE students were engaged in a process of sense making as they dialogued with the unfamiliar authoritative discourse and endeavoured to relate it to their own practical knowledges, beliefs, values, and experiences. 


\section{Discussion}

The process by which aspects of the authoritative discourse were (or were not) made internally persuasive to an individual student was quite complex because much of this negotiation occurred outside of the participants' conscious awareness and was barely discernible to the casual observer. Focused observations of their interactions with the children allowed for a nuanced look at the ways in which the cultural myths about what it means to be an educator formed in their own experiences pervaded their practices. If we consider the transparent and observable surface elements to be representative of one's professional practice, then we cannot perceive the invisible layers of deeply held cultural beliefs and values dwelling beneath the surface that inform and propel our actions (Goodfellow, 2003; Nieto, 2010). In terms of identity, the women were attempting to negotiate belongingness in multiple, disparate communities, each with very different expectations about how to teach young children. Their practices suggested that, at that point at least, the women resided within the interstices of an identity conferred by the community of practice and one established in the context of their own personal and cultural biographies.

Ameena's explanation actualizes this tension between personal or cultural ways of being with children and the authoritative discourse of professionalism: "Professional means you do how they teach you [in the ECTE program] even if they (supervisor or instructors) don't see you.... Joanne [an educator], she's more professional in how she talks to the kids, how the kids love her. Everything she does in a real way, the right way, and a real way" (interview, February 28, 2013). Joanne is perceived as holding the "right" professional knowledge, but she is also "real," acting intuitively and applying what she personally knows about children. Consistent with Wenger's (2000) work, the professional educator must be able to mobilize her personal understandings and refine the expected competencies. Since the practical knowledges of immigrant and refugee students or educators are excluded from the authoritative discourse, it is difficult for them to legitimately apply their own understandings in this manner. Essentially, these women are positioned as needing to change themselves, otherwise their learning trajectory will never lead to full, legitimate participation in the community (Wenger, 1998).

Furthermore, Wenger (1998) explains that identity is a locus of social power: "Power derives from belonging as well as from exercising control over what we belong to" (p. 207). Previous studies (e.g., Langford, 2007; Moles, 2014) have suggested that immigrant and refugee students appear to succumb to this pressure to conform, and Geena confided that she, too, felt a sense of obligation to the authoritative discourse:

I know the system is different here. I can't do anything because this is the system and the rules for day care.... Sometimes you have to follow your heart, but if you have rules, you know, guidelines, you can't do the

\section{Canadian Children}


opposite of that. You can't follow your heart everywhere. I know what to

do. I know my obligations. (interview, February 28, 2013)

Power is infused with tension in cases where belonging in the community means losing the ability to negotiate and contribute to the terms of membership. Potential outcomes include feelings of powerlessness, vulnerability, and marginality (Wenger, 1998). Alsup (2006) found that students who had difficulty envisioning themselves fitting into the established identity experienced conflicts which, in some cases, led to leaving the profession.

Geena frequently referred to the internal struggle to make the authoritative discourse internally persuasive as "making the balance" between belief systems. Such conflicts need not always be negative, but can also potentially be productive: "Our ideological development is just such an intense struggle within us for hegemony among various available verbal and ideological points of view, approaches, directions and values ... this (internally persuasive) discourse is able to reveal even newer ways to mean" (Bakhtin, 1981, p. 346). The areas of tension operationalized in their interactions with the children expose aspects of practice that are easily made internally persuasive to these immigrant and refugee students and others that are not. As these "newer ways to mean" emerge, the participants may continue drawing ideas into their conceptual systems, relating them to their own prior understandings, and dialogically (re)constructing their own professional identities. Both practice and identity are not immovable, but fluid, continuing to shift and change over time. Alsup (2006) describes such shifts as "a state of continual becoming rather than an endpoint" (p. 7).

Currently, though, the power of regulatory frameworks ensures that many ECTE programs adhere to a monologic, authoritative discourse (White, 2009) with a desired endpoint of the professional as a technician. Within the ECTE program, Miller Marsh (2003) posits, instructors need to be aware that the discourses they themselves use could either constrain or offer possibilities for students' identity construction. To disrupt this authoritative discourse, instructors must create spaces for immigrant and refugee students to form meaningful connections between their own beliefs, experiences, and practical knowledges and the course content (Gupta, 2006, 2013; Moles, 2014; Pui-Wah, 2006). Since the findings in this study demonstrate that practice is a hybridized mixture of two belief systems contained within a single action or encounter (Bakhtin, 1981), instructors and supervisors should understand that students will always retain residual traces of their beliefs (though these will change over time). If students have time and space for dialogue with the content and practices they are learning, they can populate their practice with their own intentions and meanings and make it their own. When immigrant and refugee students access their practical knowledges, they may be marginalized within their ECTE program community of practice. Their experiences are not accountable to "the regime of competence" and therefore "are repressed, despised, feared, or simply ignored" (Wenger, 
1998, p. 216). Thus ECTE programs must acknowledge the validity of multiple, polyphonic voices "with equal rights and each with its own worlds" (Bakhtin, 1984, p. 6). In this way, immigrant and refugee educators or ECTE students can imbue practice within the community with their own personal competencies and author their own legitimized professional voices in dialogue with other members of the community of practice instead of being made to feel they must adopt a universal professional identity to pass their courses. Ultimately, practices that blend personal, cultural, and professional knowledges will provide richer and more meaningful experiences for immigrant and refugee children and their families, who will be supported in their diverse ways of being and becoming.

\section{References}

Adair, J. K., Tobin, J., \& Arzubiaga, A. (2011). The dilemma of cultural responsiveness and professionalization: Listening closer to immigrant teachers who teach children of recent immigrants. Teachers College Record, 114(12), 1-37.

Agbenyega, J. (2012). How we view our theoretical competency: Early childhood preservice teachers' self-evaluation of a professional placement experience. Australasian Journal of Early Childhood, 37(2), 141-147.

Alberta Association for Accreditation of Early Learning Services. (2011). ACCAP quality standards for child care centres. Retrieved from: http://www.aelcs.ca

Alsup, J. (2006). Teacher identity discourses: Negotiating personal and professional spaces. Mahwah, NJ: Lawrence Erlbaum.

Angrosino, M. (2007). Doing ethnographic and observational research: The SAGE qualitative research kit. Thousand Oaks, CA: SAGE.

Bakhtin, M. M. (1981). Discourse in the novel (C. Emerson \& M. Holquist, Trans.). In C. Emerson \& M. Holquist (Eds.), The dialogic imagination: Four essays by M. M. Bakhtin (pp. 259-422). Austin, TX: University of Texas Press.

Bakhtin, M. M. (1984). Problems of Dostoevsky's poetics (C. Emerson, Trans.). Minneapolis, MN: University of Minnesota Press.

Bakhtin, M. M. (1986). The problem of speech genres (V. W. McGee, Trans.). In C. Emerson \& M. Holquist (Eds.), Speech genres and other late essays (pp. 60-102). Austin, TX: University of Texas Press.

Beach, J., Friendly, M., Ferns, C., Prabhu, N., \& Forer, B. (2008). Early childhood education and care. Retrieved from: http:/www.childcarecanada.org/ 
Bernheimer, S. (2003). New possibilities for early childhood education: Stories from our non-traditional students. New York, NY: Peter Lang.

Britzman, D. (2003). Practice makes practice: A critical study of learning to teach. Albany, NY: SUNY Press.

Brown, C. P., \& Feger, B. S. (2010). Examining the challenges early childhood teacher candidates face in figuring their role as early educators. Journal of Early Childhood Teacher Education, 31, 286-306. doi: 10.1080/10901027.2010.523774

Cannella, G. (1997). Deconstructing early childhood education: Social justice \& revolution. New York, NY: Peter Lang.

Cho, C. L. (2010, February 16). "Qualifying" as teacher: Immigrant teacher candidates' counter-stories. Canadian Journal of Educational Administration and Policy, 100, $1-22$.

Colley, H. (2006). Learning to labour with feeling: Class, gender, and emotion in childcare education and training. Contemporary Issues in Early Childhood, 7, 1529. doi: $10.2304 /$ ciec.2006.7.1.15

Dahlberg, G., Moss, P., \& Pence, A. (1999). Beyond quality in early childhood education and care: Postmodern perspectives. London, UK: Falmer.

Dahlberg, G., Moss, P., \& Pence, A. (2007). Beyond quality in early childhood education and care: Languages of evaluation. New York, NY: Routledge.

Egan, B. (2009). Learning conversations and listening pedagogy: The relationship in student teachers' developing professional identities. European Early Childhood Education Research Journal, 17, 43-56. doi: 10.1080/13502930802689012

Fenech, M., Sumison, J., \& Shepherd, W. (2010). Promoting early childhood teacher professionalism in the Australian context: The place of resistance. Contemporary Issues in Early Childhood, 11, 89-105. doi: 10.2304/ciec.2010.11.1.89

Feuerverger, G. (1997). "On the edges of the map": A study of heritage language teachers in Toronto. Teaching and Teacher Education, 13(1), 39-53.

Fleer, M. (2003). Early childhood education as an evolving 'community of practice' or as lived 'social reproduction': Researching the 'taken-for-granted.' European Early Childhood Education Journal, 4(1), 64-79.

Fleer, M. (2006). The cultural construction of child development: Creating institutional and cultural intersubjectivity. International Journal of Early Years Education, 14, 127-140. doi: 10.1080/09669760600661294

\section{Canadian Children}


Furlong, C. (2013). The teacher I wish to be: Exploring the influence of life histories on student teacher idealised identities. European Journal of Teacher Education, 36(1), 68-83. doi: 10.1080/02619768.2012.678486

Garavuso, V. (2013). “I'm not just gonna settle for anything:” Inciting teacher efficacy through critical pedagogies. In G. Wilgus (Ed.), Knowledge, pedagogy, and multiculturalism: Shifting the locus of learning in urban teacher education (pp. 39-62). New York, NY: Palgrave Macmillan.

Gee, J. P., Hull, G., \& Lankshear, C. (1996). The new work order: Behind the language of the new capitalism. Boulder, CO: Westview Press.

Goodfellow, J. (2003). Practical wisdom in professional practice: The person in the process. Contemporary Issues in Early Childhood Education, 4(1), 48-63.

Government of Alberta. (2013a). Child care licensing act. Edmonton, AB: Alberta Queen's Printer.

Government of Alberta. (2013b). Child care staff certification. Retrieved from: http://www.child.alberta.ca/home/1149.cfm

Gupta, A. (2006). Early experiences and personal funds of knowledge and beliefs of immigrant and minority teacher candidates dialog with theories of child development in a teacher education program. Journal of Early Childhood Teacher Education, 27, 3-18. doi: 10.1080/10901020500534224

Gupta, A. (2011). Teaching to learn and learning to teach. European Early Childhood Education Research Journal, 19, 1-4. doi: 10.1080/1350293X.2011.552284

Gupta, A. (2013). Incorporating teacher candidates' prior beliefs and funds of knowledge in theories of child development. In G. Wilgus (Ed.), Knowledge, pedagogy, and multiculturalism: Shifting the locus of learning in urban teacher education (pp. 107-128). New York, NY: Palgrave Macmillan.

Guyton, E., Saxton, R., \& Wesche, M. (1996). Experiences of diverse students in teacher education. Teaching and Teacher Education, 12(6), 643-652.

Heath, S. B. (1983). Ways with words: Language, life, and work in communities and classrooms. Cambridge, UK: Cambridge University Press.

Horsley, M. W., \& Bauer, K. A. (2010). Preparing early childhood educators for global education: The implications of prior learning. European Journal of Teacher Education, 33, 421-436. doi: 10.1080/02619768.2010.509427

Huijbregts, S. K., Leseman, P. P. M., \& Tavecchio, L. W. C. (2008). Cultural diversity in center-based childcare: Childrearing beliefs of professional caregivers from

Canadian Children 
different cultural communities in the Netherlands. Early Childhood Research Quarterly, 23, 233-244. doi: 10.1016/j.ecresq.2007.10.001

Jipson, J. (1991). Developmentally appropriate practice: Culture, curriculum, connections. Early Education and Development, 2(2), 120-136.

Karila, K. (2008). A Finnish viewpoint on professionalism in early childhood education. European Early Childhood Education Research Journal, 16, 210-223. doi: $10.1080 / 13502930802141634$

Knoeller, C. P. (2004). Narratives of rethinking: The inner dialogue of classroom discourse and student writing. In A. F. Ball \& S. W. Freedman (Eds.), Bakhtinian perspectives on language, literacy, and learning (pp. 148-171). New York, NY: Cambridge University Press.

Lamote, C., \& Engels, N. (2010). The development of student teachers' professional identity. European Journal of Teacher Education, 33(1), 3-18. doi: $10.1080 / 02619760903457735$

Landay, E. (2004). Performance as a foundation for a secondary school literacy program: A Bakhtinian perspectives. In A. F. Ball \& S. W. Freedman (Eds.), Bakhtinian perspectives on language, literacy, and learning (pp. 107-128). New York, NY: Cambridge University Press.

Langford, R. (2006). Discourses of the good early childhood educator in professional training: reproducing marginality or working towards social change. International Journal of Educational Policy, Research, \& Practice: Reconceptualizing Childhood Studies, 7, 115-125.

Langford, R. (2007). Who is a good early childhood educator? A critical study of differences within a universal professional identity in early childhood education preparation programs. Journal of Early Childhood Teacher Education, 28, 333352. doi: 10.1080/10901020701686609

Langford, R. (2010). Theorizing an early childhood educator's authority for the advancement of social goods. The Alberta Journal of Educational Research, 56(3), 291-303.

Lave, J., \& Wenger, E. (1991). Situated learning: Legitimate peripheral participation. New York, NY: Cambridge University Press.

Lirette, P. R. (2012). Child care accreditation in Alberta: An institutional ethnography. Doctoral dissertation, University of Alberta, Edmonton, Canada. Retrieved from: https://era.library.ualberta.ca/public/view/item/uuid:66b000ab-17e1-4438-9d02c001438b6fa4/ 
Lobman, C., \& Ryan, S. (2007). Differing discourses on early childhood teacher development. Journal of Early Childhood Teacher Education, 28, 367-380. doi: $10.1080 / 10901020701686633$

Lopes, A., \& Pereira, F. (2012). Everyday life and everyday learning: The ways in which pre-service teacher education curriculum can encourage personal dimensions of teacher identity. European Journal of Teacher Education, 35(1), 17-38. doi: $10.1080 / 02619768.2011 .633995$

Lubeck, S. (1996). Deconstructing 'child development knowledge' and 'teacher preparation.' Early Childhood Research Quarterly, 11(2), 147-167.

Ludlow, B. L., \& Berkeley, T. R. (1994). Expanding the perceptions of developmentally appropriate practice: Changing theoretical perspectives. In B. Mallory \& R. New (Eds.), Diversity and developmentally appropriate practices: Challenges for early childhood education (pp. 107-118). New York, NY: Teachers College Press.

Massing, C. (2014). African refugee women's songs and stories: Possibilities for diversifying literacy practices in early childhood education. In C. Brewer \& M. McCabe (Eds.), Working with immigrant and refugee families in Canadian schools. Edmonton, AB: Brush Education.

Matusov, E., \& von Duyke, K. (2010). Bakhtin's notion of the internally persuasive discourse in education: Internal to what? A case of discussion of issues of foul language in teacher education. In K. Junefelt \& P. Nordin (Eds.), Proceedings from the second international interdisciplinary conference on perspectives and limits of dialogism in Mikhail Bakhtin, Stockholm University, Sweden, June 3-5, 2009 (pp. 174-199). Stockholm, Sweden: Stockholm University.

McLaren, P. (1989). Life in schools. White Plains, NY: Longmans.

Miller Marsh, M. (2003). The social fashioning of teacher identities. New York, NY: Peter Lang.

Moles, J. (2014). A fair game or no contest? Contested identities in teacher education. Gender and Education, 26(2), 168-179. doi: 10.1080/09540253.2014.888404

Moloney, M. (2010). Professional identity in early childhood care and education: Perspectives of preschool and infant teachers. Irish Educational Studies, 29(2), 167-187. doi: 10.1080/03323311003779068.

Moss, P. (2006). Structures, understandings and discourses: Possibilities for reenvisioning the early childhood worker. Contemporary Issues in Early Childhood, 7,30-41. doi: 10.2304/ciec.2006.7.1.30 
Moyles, J. (2001). Passion, paradox, and professionalism in early years education. Early Years, 21, 81-95. doi: 10.1080/09575140120057167

Myles, J., Cheng, L., \& Wang, H. (2006). Teaching in elementary school: Perceptions of foreign-trained teacher candidates on their teaching practicum. Teaching and Teacher Education, 22, 233-245. doi: 10.1016/j.tate.2005.09.001

National Association for the Education of Young Children. (2009). Developmentally appropriate practice in early childhood programs serving children from birth through age 8: A position statement of the National Association for the Education of Young Children. Retrieved from: http://www.naeyc.org/

Nieto, S. (2010). Language, culture, and teaching: Critical perspectives. Mahwah, NJ: Lawrence Erlbaum.

Nuttall, J., \& Ortlipp, M. (2012). Practicum assessment of culturally and linguistically diverse early childhood pre-service teachers. European Early Childhood Education Research Journal, 20(1), 47-60.

Ortlipp, M., Arthur, L., \& Woodrow, C. (2011). Discourses of the early years learning framework: Constructing the early childhood professional. Contemporary Issues in Early Childhood, 12(1), 56-70. doi: 10.2304/ciec.2011.12.1.56

Ortlipp, M., \& Nuttall, J. (2011). Supervision and practicum assessment of the early childhood practicum: Experiences of pre-service teachers who speak English as a second language and their supervising teachers. Australasian Journal of Early Childhood, 36(2), 87-94.

Osgood, J. (2006). Deconstructing professionalism in early childhood education: Resisting the regulatory gaze. Contemporary Issues in Early Childhood Education, 7, 5-14. doi: 0.2304/ciec.2006.7.1.5

Osgood, J. (2012). Narratives from the nursery: Negotiating professional identities in early childhood. London, UK: Routledge.

Packer, M., \& Goicoechea, J. (2000). Sociocultural and constructivist theories of learning: Ontology, not just epistemology. Educational Psychologist, 35(4), 227241.

Pui-Wah, D.C. (2006). The translation of Western teaching approaches in the Hong Kong early childhood curriculum: A promise for effective teaching? Contemporary Issues in Early Childhood, 7(3), 228-237.

Quiocho, A., \& Rios, F. (2000). The power of their presence: Minority group teachers and their schooling. Review of Educational Research, 70(4), 485-528. 
Sachs, J. (2003). The activist teaching profession. Philadelphia, PA: Open University Press.

Service Canada. (2011). Early childhood educators and assistants. Retrieved from: http://www.servicecanada.gc.ca/eng/qc/job_futures/statistics/4214.shtml

Sherwood, S. A. S., \& Reifel, S. (2010). The multiple meanings of play: Exploring preservice teachers' beliefs about a central element of early childhood education. Journal of Early Childhood Teacher Education, 31, 322-343. doi: 10.1080/10901027.2010.524065

Souto-Manning, M., \& Dice, J. (2007). Reflective teaching in the early years: A case for mentoring diverse educators. Early Childhood Education Journal, 34, 425-430. doi: 10.1007/s10643-007-0151-1

Statistics Canada. (2010). Projections of the diversity of the Canadian population, 2006 to 2031. Ottawa, ON: Ministry of Industry.

Stenberg, K., Karlsson, L., Pitkaniemi, H., \& Maaranen, K. (2014). Beginning student teachers' teacher identities based on their practical theories. European Journal of Teacher Education, 37(2), 204-219. doi: 10.1080/02619768.2014.882309

Taggert, G. (2011). Don't we care? The ethics and emotional labour of early years professionalism. Early Years, 31, 85-95. doi: 10.1080/09575146.2010.536948

Thomas, L. (2012). New possibilities in thinking, speaking, and doing: Early childhood teachers' professional identity constructions and ethics. Australasian Journal of Early Childhood, 37(3), 87-95.

Urban, M. (2008). Dealing with uncertainty: Challenges and possibilities for the early childhood profession. European Early Childhood Education Research Journal, 16, 135-152. doi: 10.1080/135029308021141584

Vincent, C., \& Braun, A. (2011). 'I think a lot of it is common sense...': Early years students, professionalism, and the development of a 'vocational habitus.' Journal of Education Policy, 26(6), 711-785. doi: 10.1080/02680939.2010.551143

Vygotsky, L. (1978). Mind and society: The development of higher mental processes. Cambridge, MA: Harvard University Press.

Walsh, S. C., Brigham, S. M., \& Wang, Y. (2011). Internationally educated female teachers in the neoliberal context: Their labour market and teacher certification experiences in Canada. Teaching and Teacher Education, 27, 657-665. doi: 10.1016/j.tate.2010.11.004. 
Wen, X., Elicker, J. G., \& McMullen, M. B. (2011). Early childhood teachers' curriculum beliefs: Are they consistent with observed classroom practices? Early Education and Development, 22(6), 945-969. doi: 10.1080/10409289.2010.507495

Wenger, E. (1998). Communities of practice: Learning, meaning, and identity. Cambridge, UK: Cambridge University Press.

Wenger, E. (2000). Communities of practice and social learning systems. Organization, 7, 225-246. doi: 10.1177/135050840072002

Wertsch, J. V. (1998). Mind as action. New York, NY: Oxford University Press.

White, E. J. (2009). Bakhtinian dialogue: A philosophical and methodological route to dialogue and difference. Paper presented at the Annual Conference of the Philosophy of Education Society of Australasia, Imin International Conference Center, East-West Center, Honolulu, Hawaii, December 3-6, 2009.

Wilgus, G. (2006). Beyond because I said so! Three early childhood teachers challenge the research on disciplinary beliefs and strategies of individuals from workingclass minority backgrounds. Contemporary Issues in Early Childhood, 7(3), 253269.

Wilgus, G. (2013). Introduction. In G. Wilgus (Ed.), Knowledge, pedagogy, and multiculturalism: Shifting the locus of learning in urban teacher education (pp. 120). New York, NY: Palgrave Macmillan.

Woodrow, C. (2008). Discourses of professional identity in early childhood: Movements in Australia. European Early Childhood Education Research Journal, 16, 269 280. doi: $10.1080 / 13502930802141675$

\footnotetext{
${ }^{\mathrm{i}}$ In this article I use the term "teacher education" to maintain consistency with the literature. Although one-third of my participants were teachers in their home countries, they were actually studying in a one-year certificate program in a community college. I refer to individuals who are enrolled in ECTE programs as "students."

ii The field of ECE actually represents a constellation of practice comprising multiple communities of practice that are interconnected and overlapping, possibly having historical roots, members, discourses, enterprises, and working conditions in common (Wenger, 1998).
} 


\section{In this issue:}

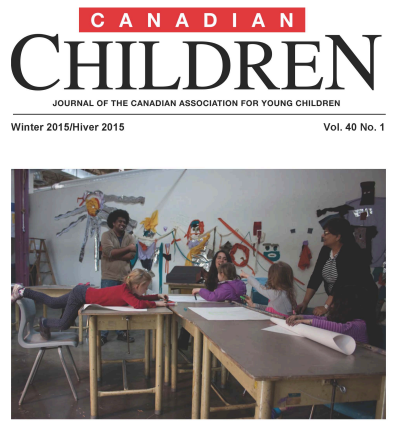

From the Editors' Desk Special Issue: Professionalism in ECEC Guest Editors: Dr. Rachel Langford, Dr. Jane Hewes, Sonya Hooper, and Monica Lysack

Beyond Professionalism: Interrogating the Idea and the Ideals by Randa Khattar and Karyn Callaghan

Negotiating Status: The Impact of Union Contracts on the Professional Role of RECEs in Ontario's Full-Day Kindergarten Program by Romona Gananatham

The Glass Ceiling Effect: Mediating Influences on Early Years Educators' Sense of Professionalism by Stefanie Tukonic and Debra Harwood

Enhancing Professionalism and Quality Through Director Training and Collegial Mentoring by Glory Ressler, Gillian Doherty, Tammy McCormick Ferguson, and Jonathan Lomotey

Authoring Professional Identities: Immigrant and Refugee Women's Experiences in an Early Childhood Teacher Education Program by Christine Massing

ECEs as Childcare Advocates: Examining the Scope of Childcare Advocacy Carried out by ECEs from the Perspective of Childcare Movement Actors in Ontario and Manitoba by Lyndsay Macdonald, Brooke Richardson, and Rachel Langford

From Child-Minders to Professionals: Insights From an Action Research Project on Prince Edward Island by Anna Baldacchino, Ray Doiron, Martha Gabriel, Alaina Roach O'Keefe, and Jessica McKenna

Pedagogical Narrations and Leadership in Early Childhood Education as Thinking in Moments of Not Knowing by Iris Berger

Find other articles from this issue at www.cayc.ca 